\title{
Honouring and Losing Knowledge: Folk Medicine Collection of the Estonian Museum of Hygiene in the Early $2^{\text {th }}$ Century
}

\begin{abstract}
Before the Estonian Museum of Hygiene was founded in 1922, a medical student, the later director of the Museum, Voldemar Sumberg (1893-1965), published an article Rahwa-meditsiin ja arstiteadus (Folk medicine and medical science) in the popular magazine Tervis (Health) ${ }^{1}$. In the article he explained the principles of understanding and collecting folk medicine and advocated bringing folk medicine and modern medicine closer together. In May 1925, the Estonian Museum of Hygiene, under Sumberg's lead, distributed their questionnaire Asuge rahva-arstiteaduse korjamisele (Start to collect folk medicine) to doctors and veterinary doctors, schools, etc.

One of the keystones of the newly-founded museum's work was collecting and, thorough analysis of the medical knowledge of "the elderly," storing that knowledge, as well as turning the public's attention to harmful medical practices. Several co-workers sent their recordings to the museum, and some senior medical students were also sent out to fieldwork to collect information on healing and healers. By 1935, a respectable amount of folk medical data had been sent in, along with various folk
\end{abstract}

1 Sumberg V. Rahwa-meditsiin ja arstiteadus // Tervis, 1922; 6: 41-47. 
medical instruments. The results of this collecting campaign have, however, been forgotten, largely due to the arrest and deportation of Voldemar Sumberg by the Soviet forces and the destruction of the Museum and its collections by the early 1950s.

Relying on the documentation and archival material being preserved in several museums and archives in Tartu and Tallinn (the Estonian Health Care Museum², the Estonian State Archives, the Estonian Historical Archives, the Estonian Folklore Archives and the Estonian National Museum), this article will give an overview of the fate of the folk medicine records and items collected by the Museum of Hygiene during the 1920s and 1930s and Voldemar Sumbergs role in it. It also sheds some light on the attitude of the physicians of the time toward folk medicine and the restoration of the Health Care Museum. ${ }^{3}$

The questionnaire of the Estonian Museum of Hygiene for collecting knowledge of folk medicine was found by the author of this article quite accidentally, from the Estonian Folklore Archives while composing her $\mathrm{PhD}$ thesis ${ }^{4}$. The fact that such a museum had been interested in collecting folk medicine records was intriguing. The questionnaire concentrated on gathering knowledge on all kinds of folk healing techniques, and - an uncommon feature of the questionnaires of that era - additionally included questions on the healer's knowledge of human body and functions of several organs. The questionnaire also requested that the respondents collect manuscripts, folk healing instruments, charms and herbs. It is important to point out that the approach of this questionnaire is not condescending, as was usual for the medical circles of the time, but showed great understanding and knowledge of folk belief and healing.

2 The Estonian Health Care Museum is successor of the Estonian Museum of Hygiene. The Estonian Health Care Museum was (re)founded in 1980 in Tallinn. There is a difference in the English versions of the name of the museum, in Estonian the name was and is Eesti Tervishoiu Muuseum.

3 This article is a continuation and an elaborated version of Tupits, 2010.

4 Tupits A. Käsitlusi rahvameditsiinist: mõiste kujunemine, kogumisja uurimistöö kulg Eestis 20. Sajandil // Dissertationes Folkloristicae Universitatis Tartuensis 13. (Aspects on Folk Medicine: Development of the Definition, Data Collecting and Research in Estonia in the $20^{\text {th }}$ Century). - Tartu: Tartu Ülikooli Kirjastus, 2009. 
The man who was definitely behind this questionnaire, Voldemar Kristjan Sumberg (28 $8^{\text {th }}$ March $^{5}, 1893$ to $13^{\text {th }}$ February, 1965) was an Estonian doctor and director of the Estonian Museum of Hygiene. He studied medicine in Tartu in 1915-1918 and in 1920-1922. During the Estonian War of Independence (1918-1920) he acted as a medical assistant in the army. In 1922, he worked as a voluntary assistant at the Health Care Institute of the University of Tartu. On 1 December 1922, he was appointed as a clerk of the Museum of Hygiene. In 1923, he was elected a Junior Assistant of the Health Care Institute and from 1 January 1925, was released from this position on his own request, as his duties at the Museum demanded more time. During his university years, he was a member of the Estonian Students' Society ${ }^{6}$. Alongside his position as the director of the Museum, he edited a popular magazine Tervis from 1928-1944 7,8.

In 1944, he was appointed the Minister of Social Affairs in the Otto Tief government", and, because of this involvement with the "bourgeois government", he was arrested and deported by the Soviet forces. He was

$59^{\text {th }}$ April according to the new calendar.

6 The Estonian Students' Society was founded in Tartu in 1870. It functioned from 1870-1940 in Tartu, was banned during the Soviet era and had to act in secrecy. From 1945 its branches were active in several countries in Europe and in the USA. A large number of political and social leaders are alumni of this society.

7 The first digit in the reference system of the Estonian State Archives (ERA) and the Estonian Historical Archives (EAA) refers to the fonds, the second to the inventory and the third to the file. The following digits point to the page number and the letters ' $r$ ' and ' $v$ ' are indicating either recto or verso of the page.

8 Sumberg Voldemar, young assistant // EAA.2100.2.1153: 1r-6v, 22r, 30r-31v.

9 The government of Otto Tief (20-22 September 1944) remained the last legal government of the Republic of Estonia until the country regained its independence in 1991. In September 1944 German troops retreated from Estonia and in the quest to protect the country from Soviet attack, the underground independence movement decided to restore the Republic of Estonia, and thus to attempt to seek help from the West in case of attack. The Soviet Union attacked Estonia at the end of September and occupied the country. Members of the Estonian government were either arrested and deported to Siberia or killed, although some managed to flee to foreign countries. The significance of this lies in the continuing independence of Estonian government abroad during the Soviet occupation. 
released from a forced labour camp in Siberia in 1954 and was able to make a short visit to Tartu in 1960, but was not allowed to return to Estonia permanently. He died as a highly acclaimed doctor and director of a holiday home in Targai (Siberia, Novosibirsk oblast).

\section{The Hope of Uniting Folk Medicine and Academic Medicine}

In March 1922, Voldemar Sumberg's article Rahwa-meditsiin ja arstiteadus (Folk Medicine and Medical Science) was published in the magazine Tervis. ${ }^{10} \mathrm{~A}$ draft of this article has been preserved at the Estonian State Archives (ERA) ${ }^{11} 12$, bearing some differences to the printed version.

In the article, Sumberg was very positive about folk medicine. He wrote that a doctor had to near himself to the soul of a man - this is exactly what a healer could do, but the doctors could not. This brings up the necessity for academic medicine to get to know folk medicine. ${ }^{13},{ }^{14} \mathrm{He}$ emphasised that it was difficult to collect folk medicine ${ }^{15}$, referring to the folk belief rule of keeping silent about the healing procedures and charms. Sumberg's goal in this article was to bring folk medicine and academic medicine closer together - as he wrote, folk medicine could enrich the academic medicine.

10 Sumberg V. Rahwa-meditsiin ja arstiteadus // Tervis, 1922; 6: 41-47.

11 The funds of the Estonian Museum of Hygiene (ERA.4617, 1924-1942) at the Estonian State Archives were taken over from the Historical Archives to the State Archives in 1974 and reorganised in 1989. The funds consist of 156 files, which were catalogued into one inventory on the basis of chronological-nominal characteristics. A pre-word was compiled for the funds. The files are: newsletters, instructions, presentations, programmes, photos, budgets, reports, reviews, correspondence, lists, questionnaires, invoice books, register books, and personnel files. (This information can be found in AIS (www.ais.ee) - the information system and search engine of the Estonian Historical Archives.)

12 Folk medicine manuscripts sent to the Museum by private individuals: List of folk healers. 05.07.1925-17.12.1925. // ERA.4617.1.26: 54r-77v.

13 Ibid, 73r, 74r.

14 Sumberg V. Rahwa-meditsiin ja arstiteadus // Tervis, 1922; 6: 47.

15 Folk medicine manuscripts sent to the Museum by private individuals: List of folk healers. 05.07.1925-17.12.1925. // ERA.4617.1.26: 76r. 
He also stressed the importance of folk medicine on a broader level: "Folk medicine is a barometer of the cultural surface in a particular location and has, as such, also ethnographical and culture-historical importance". It was in his opinion important to immediately and thoroughly collect old and new ways of healing, instruments of healing, herbs and stories about healing, etc. He also proposed that a dictionary of Estonian folk medicine should be compiled.

When comparing the draft and the final, published version of his article, it is clear that Sumberg rearranged his text quite a bit and tried to find the best possible wording to bring out his point. In the original draft it is also interesting to notice his efforts to find the best terminology - for example he used the term arstiteadus (medical science) instead of meditsiin (medicine) in both the academic and the folkloric context; in the draft he also made use of the term ülikooli arstiteadus (university medical science) that had been corrected into ülikooli meditsiin (university medicine) in the draft and finally appeared as "medical science" in the printed text. In addition, Sumberg made use of the term modern arstiteadus (modern medical science).

If there is bigger faith in the doctor, the number of patients will also rise, Sumberg wrote. He pointed out that the folk did not care if it was the church, the gods or the past beliefs that helped them, one still had to get along well with all of them. The feeling for belief and the need for it are great, which means, one cannot look down upon it. Nevertheless, folk medicine often becomes senseless because of the belief factor, so that the administrative powers are forced to intervene. ${ }^{16}$ In the draft of his article, Sumberg discussed the psychological influences related to falling ill and curing the illness. ${ }^{17}$ Also in the draft, he mentioned several cases (of course, not mentioning any names), where healers had helped respected people in the society. For instance, he referred to a personal acquaintance, an advocate's wife, whose child had been cured from a skin disease by a healer, and an important statesman whom the modern medical science had not been able to help for a long time but who had been

16 Folk medicine manuscripts sent to the Museum by private individuals: List of folk healers. 05.07.1925-17.12.1925. // ERA.4617.1.26: 60r.

17 Ibid, 66r, 67r. 
cured by a healer. ${ }^{18}$ All these examples have, however, been removed from the final version of the article.

He also wrote that folk medicine is no ancient science, but as it has been tested for a long time, it competes with modern medicine and could only enrich the latter. ${ }^{19}$ He believed nevertheless that in the form it had at the time, folk medicine was quite harmful. ${ }^{20}$ In the draft he also named some of the scholars from the $19^{\text {th }}$ and $20^{\text {th }}$ centuries, who had already collected folk medicine (e.g. Jakob Hurt, Ferdinand Johann Wiedemann, Ilmari Manninen); ${ }^{21}$ none of these names appear in the article. At the end of his draft, he presented the question - who should be collecting folk medicine - but there was no clear answer following the question, except a hint towards the Academic Society of Medicine.

In 1921, Sumberg had been involved in the compilation of a questionnaire Rahva arstiteaduse korjamise kava (The Programme for Collecting Folk Medical Knowledge), ${ }^{22,} 23,24$ which was published by the Estonian National Museum (founded in 1909) in collaboration with the Medicine Section of the Estonian Students' Society. ${ }^{25}$ In connection to this early 1920 s collecting work, another medical society played its part.

The Academic Society of Medicine was founded on 30 March 1922 and started its meetings in September the same year. One of its tasks was to study and collect popular healing traditions and methods. The Society

18 Folk medicine manuscripts sent to the Museum by private individuals: List of folk healers. 05.07.1925-17.12.1925. // ERA.4617.1.26: 68r.

19 Ibid.

20 Ibid, 69r.

21 Ibid, 77v.

22 Sumberg V. Rahva arstiteaduse korjamise kava / Eesti Rahva Muuseumi väljaanne 17. "Eesti Üliõpilaste Seltsi" arstiteaduse osakonna toimetus. - Tartu: J. Mällo trükk, 1921.

23 Indication of Voldemar Sumberg as the compiler of the questionnaire is based on data found in the general register of Estonian books in 1928-1923 (Antik 1931: 278). The compiler's name is not printed on the questionnaire.

24 Sumberg V. Rahwa-meditsiin ja arstiteadus // Tervis, 1922; 6: 46.

25 Tupits A. MD Voldemar Sumberg and the Folk Medicine Collection of the Estonian Museum of Hygiene from the 1920s and 1930s / Tartu: Estonian Literary Museum, Estonian National Museum, University of Tartu // Journal of Ethnology and Folkloristics, 2010; 4 (2): 19-30. 
seemed to be quite active and presentations were quite regularly given by students and professionals on various medical and related topics. At a Society meeting on 8 May 1922, Sumberg suggested that students should use their vacation to collect folk medicine. ${ }^{26,27}$

At a meeting on 23 November 1923, Sumberg gave a lecture "The need to collect folk medicine and the meaning of it". There again he mentioned that folk medicine, in the state it was at time, caused more damage than it did good but that it did have a scientific element to it, which could enrich modern medicine, and also a certain worth from the ethnological and cultural-historical perspective. ${ }^{28}$ Voldemar Sumberg urged other medical students to collect folk medicine and handed out questionnaires of the Estonian National Museum. According to a short report, this undertaking had already been planned before but had not been carried out during the first six months of the activity of the Academic Society of Medicine due to the summer break. ${ }^{29}$

Another paper on Estonian folk medicine was given by stud. med. Hugo Orro on 6 February 1924. He said that Estonian folk medicine knew three ways of curing: one was based on magic (charms, incantations), the other was magic with substances; in his opinion, neither of the two had a curing effect. Thirdly, he mentioned substances which were close to modern healing and could be found in pharmacopoeia. Apparently he also mentioned several illnesses and their folk cures, but these are not listed in the report. He also mentioned some names of older folk healers. ${ }^{30}$ Sadly, the report of the paper has no further details.

26 Talvik S., et al. (Ed.) Akadeemilise arstiteaduse seltsi koosolekute protokollidest // Eesti Arst, 1923; 5/6: 170-173.

27 Bürger G. Akadeemilise arstiteaduse seltsi tegevusest tema esimesel aastal 1922/23 // Tervis, 1923; 10/11: 124-126.

${ }^{28}$ Sutt E. Akadeemilise Arstiteaduse Seltsi koosolekud // Eesti Arst, 1925; 5: $156-158$.

29 Bürger G. Akadeemilise arstiteaduse seltsi tegevusest tema esimesel aastal 1922/23 // Tervis, 1923; 10/11: 125-126.

30 Sutt E. Akadeemilise Arstiteaduse Seltsi koosolekud // Eesti Arst, 1925; 5: $156-158$. 


\section{The Estonian Museum of Hygiene}

After the first Convention of Physicians of the League of Estonian Physicians along with a medical exhibition at the end of 1921, the idea emerged to form a permanent health care exhibition - the Museum of Hygiene, which would help to explain the public the possibilities in the prevention of diseases. Some money and pieces of furniture left from the original exhibition were supposed to be given to the museum. The task of formation of the Museum was given to the Tartu Society of Estonian Physicians. The Estonian Museum of Hygiene was officially founded in Tartu on 22 November 1922, and opened to the general public on 21 December 1924. The following council was elected for the Museum: Professor Aleksander Rammul, Professor Aleksander Paldrock, MD Otto Tomberg, MD Gustav Kroll, and Assistant Professor Johannes Blumberg. Voldemar Sumberg, then still a student of medicine, was appointed a clerk for the museum. ${ }^{31}$ In 1928-1944, the museum also had an affiliate in Tallinn.

When discussing the Museum's budget for the years 1923 and 1924, the Tartu Society of Estonian Physicians voiced some strong arguments of disbelief against the planned activities. Some suggested a more modest start and beginning with collecting medical antiquities (e.g. folk medicine). The budgets were, nevertheless, approved as planned, which gave Voldemar Sumberg the possibility to visit several healthcare museums in Europe (Berlin, Dresden, Amsterdam, Paris, Helsinki, etc.) in 1924, to familiarise himself with modern ways of a healthcare museum. ${ }^{32}$ The Deutsches Hygiene Museum in Dresden in particular acted as a role model of a modern healthcare museum and was a constant partner. The Estonian Museum of Hygiene also had contacts with a number of booksellers and film distributors in Europe for ordering teaching materials (books, films, posters, etc.) regarding health behaviour.

In 1925, Sumberg introduced the work of the Museum to a wider audience in an article, mentioning that in addition to developing a modern medical collection, the Museum also collected folk medicine, i.e. all

31 Sumberg V. Eesti Tervishoiu Muuseum 1924-1934. - Tartu: Eesti Tervishoiu Muuseumi väljaanne 85, 1935. - Pp. 11-14.

32 Sumberg V. Eesti Tervishoiu Muuseumi saamisloost ja arenemisest // Eesti Arst, 1938; 1: 38-39. 
medicines, healing instruments, charms and traditions used by the folk; in order to save them from the inevitable perishing due to the progress of education. ${ }^{33}$

One of the archival documents on Estonian Museum of Hygiene, now preserved at the Estonian State Archives, also stated that the Museum of Hygiene was the centre for collecting folk medical data with the aim of helping to turn public attention to harmful medical practices and fight against them. ${ }^{34}$ The Museum was very active in giving public lectures on health care and sanitation (also over the radio), organised and participated in several exhibitions to teach the public proper health care, and published informational materials on the topic.

In 1927, a small overview of the Museum was given in the magazine Estonian Physician. At the time, the museum was located on $200 \mathrm{~m}^{2}$ in the premises of the Institute of Hygiene at Aia (now Vanemuise) Street in Tartu. Next to the departments of anatomy and physiology, dental hygiene, nutrition, mother and child care, TB and sexual diseases, clothing, first aid, and alcohol; there was a separate department dedicated to folk medicine with instruments for cupping, blood-letting and self-made instruments for pulling out teeth on display. The author of the article comments somewhat disparagingly the "bad blood" and "healthy teeth" of the country folk. It is also mentioned that the Museum had been able to collect items and data on folk medicine all over the country and find co-workers for the task. The Museum also had plans to find larger space by buying a property and being able to open several new departments. ${ }^{35}$

This plan was realised in 1928, when The League of Estonian Physicians along with the Museum bought a three-storied house just around the corner from the Museum's former location and re-opened to public in April 1929. Deemed one of the most exemplary Baltic, and perhaps even Western European, health care museum of the time, the museum

33 Sumberg V. Eesti Tervishoiu Muuseumi ülesanded rahva tervishoiu alal // Tervis, 1925; 1-2: 18-20.

34 Newsletters, instructions, programmes, photographs, manuscripts of presentations, and articles on the organisation of the museum's work and the popularisation of knowledge on healthcare. Budgets of itinerant exhibitions. 1924 // ERA.4617.1.10: 24r.

35 Ibrus A. Eesti Tervishoiu Muuseum // Eesti Arst, 1927; 3: 99-103. 
had laboratories, workshops (the Museum produced most of its exhibition items, such as papier-mâché models, wax casts, but also first-aid kits itself), apartments for service staff in the basement and an apartment for the director of the museum on the third floor. The first floor housed displays on human anatomy, physiology and nutrition, dental hygiene, infectious diseases and parasites, TB, sexual diseases and alcohol, school hygiene and PE. On the second floor, there were displays on baby heath care, sanitation in apartments, first aid, folk medicine and occupational healthcare. The second floor also had a spacious lecture room with equipment for showing slides. ${ }^{36}$ In addition, the Museum had a library with a reading room, and a film and slide collection. Unfortunately, no description of the display and contents of the folk medicine collection have been found.

In 1941, the Museum was placed under the control of the House of Sanitary Education and, after the arrest of Sumberg in 1944, the Museum was gradually going down; by 1952, there was only one room left of the Museum. ${ }^{37}$ Today, the Estonian Medical Association, the legal successor of the League of Estonian Physicians, again holds an office in the house.

\section{The Estonian Museum of Hygiene is Collecting Folk Medicine}

The short and precise questionnaire Asuge rahva-arstiteaduse korjamisele (Start to Collect Folk Medicine, EFAM, ERA 18 A) was found among the records on the history of Estonian folkloristics preserved in the Estonian Folklore Archives. ${ }^{38}$ The main emphasis was put on folk

36 Ibrus-Määr A. Tervishoiu Muuseum uutes ruumides // Eesti Arst, 1930; 8: $311-314$.

37 Markovitš L. Dr. Voldemar Sumberg ja Eesti Tervishoiu Muuseum / Dr. Voldemar Sumberg ja Eesti Tervishoiu Muuseum. Meditsiiniajaloopäevade ettekandeid. Tallinn: Eesti Tervishoiu Muuseum, 1995. - Pp. 3-9.

38 So far, only one copy of the Museum's questionnaire has been found. For now, there has been no indication that this questionnaire could also be among the Museum's files at the Estonian State Archive. A copy of this questionnaire preserved at the Estonian Folklore Archive in the file EFAM, ERA 18A bares the signature Ed. Treu, from the Estonian folklorist Eduard Laugaste 
knowledge on healing and avoiding illnesses; it mentions the spotted truths of tried and tested medicine and the ways and means of healing and determining harmful practices. It is said that folk medicine has not been collected extensively enough, so some things have already been lost, and that what is still left, has to be saved from disappearing. The potential collectors were taught where and how to collect - to do it close to home, to note down rules on magic, plants, ways of healing and charms, to collect manuscripts and books, healing instruments, to ask for detailed information from the healer or his/her patients.

This questionnaire contains questions on folk healing instruments and the knowledge of biology of the healers - what is known to the healer of the anatomy and bodily functions; what is thought to be the functions of: 1) liver, 2) spleen, 3) kidneys, 4) blood, 5) brain, 6) heart. Supposedly, the answers were expected to determine if a given healer was to be taken seriously from the viewpoint of the modern medicine; on the other hand, it would also provide with the information on folk pathology. This also connects to the rationality-irrationality searches popular at the time. It is unclear who exactly had drawn up the questionnaire.

All folk medicine related answers to the questionnaire found so far are located in the same archival file of the Estonian State Archives that also contains notes from Sumberg, drafts of his article from 1922, cut-outs from newspapers and the like. ${ }^{39}$ All this material has been bound together without sytemisation.

(1909-1994 (Treu until 1935)) in the top left hand corner. It is possible, that Eduard Laugaste and Voldemar Sumberg had also personal contacts before Sumberg's deportation. Another possibility is that this particular sheet of questionnaire might have been moving from hand to hand, finally ending up among the papers of Eduard Laugaste. It is also noteworthy that Sumberg was close friends with a medical historian and MD Herbert Normann (1897-1961), whose wife Erna Normann (1904-1978) was a folklorist. This acquaintance might have had some impact on the events described in this article. The files in the personal archive of Herbert Normann in the University of Tartu Library, however, reveal nothing in particular on his connection to Voldemar Sumberg and the folk medicine collection of the Estonian Museum of Hygiene.

39 Folk medicine manuscripts sent to the Museum by private individuals: List of folk healers. 05.07.1925-17.12.1925. // ERA.4617.1.26. 
In 1924, ${ }^{40}$ the Museum of Hygiene sent out postcards with two questions on them -1 ) if there were folk healers in a given region, 2) who in the area was interested in folk medicine and would be ready to become the Museum's correspondent. 823 postcards were sent to doctors, pharmacists, veterinary doctors, teachers, and others. 589 (71\%) replies were received. The correspondents provided names, domiciles and specialties of 394 healers, and 218 people registered as correspondents to the Museum. ${ }^{41}$ This information resulted in the formation of a separate register for folk healers and correspondents ${ }^{42}$ (now also in the Estonian State Archives), which was put together using the answers from question-postcards and consisted of simple hand-drawn tables with information on folk healers' domiciles, their working areas, and contacts of Museums correspondents.

The Museum's budgets ${ }^{43}$ demonstrate the annual funds allocated for collecting folk medicine, including remuneration for the collectors. ${ }^{44}$ Between 1923 and 1926, the Museum had planned 50,000 Estonian marks (500 Estonian kroon $^{45}$ ) for collecting folk medicine. In 1927-1929, the planned amount was 40,000 marks; in 1929-1930 - 300 kroons; in 1931-1932 500 kroons; in 1932-1933 - 200 kroons and in 1933-1934 the amount was only 100 kroons. The comments in the budgets from the years 1931-1934 also indicate a co-operation with the Academic Mother Tongue Society ${ }^{46}$ on collecting folk medicine. From the archival documents of the latter, it is

40 Personal archive of Viktor Kalnin. - S. 361, 52.

41 Sumberg V. Eesti Tervishoiu Muuseum 1924-1934. - Tartu: Eesti Tervishoiu Muuseumi väljaanne 85, 1935. - Pp. 60-61.

42 Register of folk healers with data on speciality and domicile // ERA.4617.1.154.

43 Budgets with extras, from 1923, 1924, 1927, 1929-1941 // ERA.4617.1.3: 13r, 13v; 16r; 21r; 22r; 24r; 27r; 28v; 42r; 46v; 52r; 54r; 86r.

44 It is possible that this remark has to do with the medical students engaged in fieldwork. On the other hand, it is clear from the registers that on request, money was paid also to voluntary co-workers for their information. 100 Estonian marks $=1$ Estonian kroon (pre-WW II Estonian currencies). The monetary reform (from mark to kroon) took place in 1928.

46 The (Academic) Mother Tongue Society is a philological society founded at the University of Tartu in 1920. According to www.ais.ee, the archival data on the Society's early period (1920-1945) has considerable gaps. During the WW II Society's rooms along with some of its property were destroyed. Another part of the possessions (dialect collections, books, etc) were evacuated. 
clear that in 1930 the Society's Dialect Board decided to refer to a number of institutions for financial help, including the Estonian National Museum, the Folklore Archives and the Museum of Hygiene among the others. ${ }^{47}$ At least in the years 1930-1932 the Dialect Board gave scholarships to students who, among other data, collected vocabulary and dialect records on health, illness, death and healing-related vocabulary. ${ }^{48}$ This may have been the cooperation mentioned in budgets of the Museum of Hygiene, yet clear indications of that have been difficult to find.

The budget documentation of the Museum shows that for the year 1925, the Museum had planned two scholarships for students, both in the amount of 8000 Estonian marks for three months of fieldwork. It is also mentioned in the budgets that the collection of folk medicine had already begun in due cooperation with the Academic Society for Medicine. Now, it was necessary to send students to do some further fieldwork. ${ }^{49}$

With the help of the registers of incoming and outgoing letters, three students who collected folk medicine could be identified: Voldemar Kiss (1901-1977), Arnold Reiman (1903-1963) and Karl Kaur (1900-1972). In June-July 1926, V. Kiss was conducting his research in south-west Estonia (Vana-Vändra) and K. Kaur in south-east Estonia (Räpina). It is unclear, where exactly Arnold Reiman was; there is some vague indication that he might have been doing his practice at the Museum.

The students received guidelines by mail, they had to keep a diary, and send their current addresses and work-plans, as well as all the collected material to the Museum. ${ }^{50}$ For instance, according to the entry in a register, in the end of June 1926 Karl Kaur wrote that it was difficult to collect folk medicine as everybody shied away from him. ${ }^{51}$

47 Minutes of the meetings of the Dialect Board. 17.10.1933-23.01.1937. // ERA.R2362.2.55: 8 .

48 Assignments for collectors of dialect for questioning 1929-1938 // ERA.R2362.2.57: 308; 334; 339.

49 Estonian Museum of Hygiene newsletters and budget for 1925 // Copies of outgoing correspondence on organisation of the museum's work, publication of scientific works, holding lectures and showing films. 19.12.1924-30.12.1925. // ERA.4617.1.11: 39v.

50 Register of outgoing correspondence. 02.11.1926-07.04.1929 // ERA.4617.1.43: 27r.

51 Register of incoming correspondence 22.09.1922-31.07.1926. // ERA.4617.1.2: 63v. 
The students had certificates from the Museum, stating that they had been sent out to collect folk healing practices and asking everybody to help them. ${ }^{52}$ In addition, Voldemar Kiss was also on fieldwork in the summer of 1927.53 This information is based on the entries in the registers of incoming letters.

Luck often plays its part in research, also in this study. A postcard from Karl Kaur to Arnold Reiman from the summer of 1926 has withstood time, being paginated unbound between a register of incoming letters.

Räpina 15.VII 26

\section{Arno!}

I received the photographic camera only on the $12^{\text {th }}$ of this month - I was waiting for it in Petseri [Pechory] and was therefore late to Leevi where I finally got the news of its whereabouts. I have already taken some photographs but I must confess that not everyone is ready to allow taking pictures. Some want a copy and so on. - I can't make any promises either, I mean, the Museum will not be sending pictures to them.

I will finish my work on July 16, i.e. tomorrow. I plan to arrive in Tartu and deliver my records by next Monday. - Can't say that I have loads of material, but I still have achieved quite a lot and gathered experience on how a folk healer should be researched. Greetings, Kaur. ${ }^{54}$

A handwritten addition has been made to one machine-typed archival document, stating that in the year 1925, 3778 lines of folk medicine were collected, while the English version of the same account refers to 8778 lines. $^{55}$ Another account from the years of 1926-1927 states that two students had gathered 5728 lines of folk medicine during one month (the exact month is not specified in the document and students have been left anonymous). This account reveals that the students had a photo camera

52 Register of outgoing correspondence. 28.05.1925-06.12.1926 // ERA.4617.1.31: 51v.

53 Register of incoming correspondence. 01.08.1926-28.11.1929 // ERA.4617.1.42: 35r.

${ }^{54}$ Register of incoming correspondence 22.09.1922-31.07.1926. // ERA.4617.1.2: $66 r$, v.

55 Newsletters, instructions, programmes, photographs, manuscripts of presentations, and articles on the organisation of the museum's work and the popularisation of knowledge on healthcare. Budgets of itinerant exhibitions. 1924 // ERA.4617.1.10: 6r, 24r. 
to photograph active healers, their homes, etc. In addition, many people sent in valuable data about folk healing. ${ }^{56}$

Also, according to Sumberg's article from 1935, the students had collected 878 lines (compare to the digit in previous paragraph). The rest had been collected by museum's correspondents. There were 16563 lines of folk medical records altogether. ${ }^{57}$ It is possible, however, that by referring to 878 lines, Sumberg had only the year $1934 / 1935$ in mind.

It is sometimes difficult to tell who could be the authors of a particular letter or note in the file. ${ }^{58}$ But it is still possible to find most of the names with the help of the registers of incoming letters and, in several cases, the letters, mostly written by private persons, do have names on them. It has been possible to identify about 25 names. It is also possible that some of the carefully written-out pages belong to students, for instance, there are some pages on the folk medicine of Setos, a minority nation from south-east Estonia, the region where Karl Kaur was sent to collect.

Among the data preserved in the manuscript, ${ }^{59}$ there was one answer including reference to organs, namely heart and brain: "The heart was believed to be the leader of all strength (as was the brain)". ${ }^{60}$ Most letters describe how to heal with different plants; correspondents give information about different folk-belief healing methods for toothache, skin diseases, headache, erysipelas, etc. From the folkloristic point of view, 99\% of the gathered data seriously lacks context - where, when, from whom, and how exactly was the information collected (although the same applies to most of the folk medical material gathered at the time). Therefore, the analysis of the folk medical data (which will hopefully be dealt with in a consequtive article) in the Museum's collection, is bound to be quite onesided and without contextual "flesh".

56 Reports of the Museum's work, with additional material. 1923, 1926/27 and 1935/36-1939/40 // ERA.4617.1.130: 122r.

57 Sumberg V. Eesti Tervishoiu Muuseum 1924-1934. - Tartu: Eesti Tervishoiu Muuseumi väljaanne 85, 1935. - Pp. 60-61.

58 Folk medicine manuscripts sent to the Museum by private individuals. List of folk healers. 05.07.1925-17.12.1925 // ERA.4617.1.26.

59 Ibid.

${ }^{60}$ Ibid, 3v. 
Today, around 2000 lines of folk medical records can be counted within the mentioned file. It is unclear where the rest of the answers and question-postcards may be. In addition to the manuscripts (letters from correspondents), healing instruments had been sent to the Museum. Sumberg mentioned four persons who had sent in instruments; 61 it is unclear, however, how many instruments exactly the Museum had and from how many people in total they had been received.

The documentation has not revealed how much of the collected material was on display among the exhibits in the Museum of Hygiene. So far only one photo from the instruments collection has been found published in the magazine Tervis. ${ }^{62}$ It depicts instruments for blood-letting and cupping, apparently parts of permanent exhibition.

Research in the Estonian National Museum, which holds large collections on ethnographic items, gave no clear indications that something from the Estonian Museum of Hygiene folk medicine collection (such as the medical instruments or photos) could have ended up there.

The Museum's documentation also gives indications that (at least) V. Sumberg gave some public lectures on the topic of folk medicine, for instance, on first aid in folk healing tradition. ${ }^{63}$

\section{MDs on Superstition, Folk Healing and "Non-Curing"}

While working as the director of the Estonian Museum of Hygiene, Voldemar Sumberg was also editing the popular magazine Tervis (Health), the time when traditional healing methods were considered timely, therefore discussed and illustrated on the pages of this magazine.

In 1929, the Institute of Forensic Medicine of University of Tartu sent out questionnaires to physicians all over Estonia to map the activities and background of Estonian healers and quacks. The result was that there were over 300 healers, some of them working as mid-wives or

\footnotetext{
${ }^{61}$ Sumberg V. Eesti Tervishoiu Muuseum 1924-1934. - Tartu: Eesti Tervishoiu Muuseumi väljaanne 85, 1935. - Pp. 60-61.

62 Eller M. Ärge laske verd // Tervis, 1928; 12: 196-197.

63 Outgoing correspondence of the Estonian Museum of Hygiene. 14.01.192629.12.1926 // ERA.4617.1.33: 162r.
} 
pharmacists on regular basis. Most of the healers were farmers. This figure meant that there was one healer to every 2-3 doctors (the number of doctors in Estonia in 1929 was 868), which was worse than in the neighbouring country Latvia ( 1 healer to 3-4 doctors). In some locations the number of healers was high, which was explained by the lack of local physicians. ${ }^{64}$

Later that same year (1929), during a Physicians' Conference in south Estonia, a discussion on the situation of folk healing in the country emerged. A fellow MD Siegfried Lind (who had also collected folk medicine during Sumberg's 1921 campaign) accused the magazine Tervis of publishing harmful suggestions. The physicians present also expressed a need for trust between the doctor and the patient and a need to dwelve deeper into the spiritual issues of the patient. It was found that the large amount of ebaarstid (non-doctors) signalled the lack of qualification of professional physicians and that a lot of explanatory work needed to be done. A physician would need to step closer to the public, and better education in primary schools would not be a solution. Sumberg claimed that turning to non-doctors stems from lack of education - if there were no users, there would be no non-doctors. He also stressed that the Tervis was fighting against non-curing and the suggestions published there were harmless. The Museum was further accused of stepping out of its role and dealing with spreading prophylactic knowledge. It was suggested that the Museum should remain a Museum and not interfere with the work of clinics. During closing arguments, MD Siegfried Talvik expressed his wish to make the punishments to the non-doctors more severe, and Sumberg in turn wished that anything concerning non-doctoring in Estonia would be studied by appropriate institutions (he probably meant the Museum). 65

In 1930, in a short article without an author (presumably it was written by the chief editor Sumberg) folk healing beliefs and customs related to healing traditions were disparaged. In this short article with examples from south-west Estonia, Pärnumaa, several children's diseases as well as the habit of blood-letting were described. The so-called non-doctors were

64 Rooks G. Ebaarstimine Eestis // Eesti Arst, 1929; 10: 377-378.

65 Eesti Arst (1929) // Lisa. VIII. Eesti Arstidepäev Võrus 31. augustil ja 1. septembril 1929. Aastal. Protokollid: 61-62. 
accused of abusing both the possibility of buying medicines from pharmacies, as well as people's ignorance. Two known healers were mentioned (without names) - one, who cured with magnetized water and laying hands and another who treated cancer patients with all sorts of tablets and creams. Readers were given a hint to rather go and see educated doctors. ${ }^{66}$

In 1934, in the sub-section "Mental Health," both Voldemar Sumberg and another MD, Viktor Hion, wrote about superstitions, their negative influence on people's health behaviour, and the bad outcomes of self-suggestion. Viktor Hion mentioned schoolchildren as victims of such behaviour, also those with little self-esteem, those in love and actors in theatres. In his opinion, the reasons for superstition lay within lack of courage in life and lack of ambition in one's profession. Sumberg, for instance, pointed out in his article that a modern doctor would use both academic knowledge and psychology (compare to 1922), whereas a non-doctor or faith healer could do much harm by using suggestion. Forbidding the activities of a non-doctor would, in writers' opinion, serve as the best advertisement to such a dangerous activity. 67,68

In one of his articles in the magazine Tervis in 1938, MD Siegfried Lind mentioned that physicians have found it necessary to fight against folk healing or ebaarstimine (non-curing), which should be a responsibility of the relevant institutions. As an institution which deals with studying nondoctors, the Estonian Museum of Hygiene is named. According to S. Lind, healing by these non-doctors had become prohibited and criminally punishable since 1934. ${ }^{69}$ Folk healers have been named as "non-doctors" also in some other articles and studies of that time.

The reader cannot but notice the change in Sumberg's tone in his public articles on folk medicine and folk healing between 1922 and the 1930s. It may very well be that as a young and eager medical student, it was a lot easier to be a visionary and more open-minded to alternative practices and views, as well as the dream of cooperation between traditional and

66 Tervis: Kui tervis on odav // Tervis, 1930; 3: 44-46.

67 Hion V. Miks on inimesed ebausklikud? // Tervis, 1934; 1: 6-10.

68 Sumberg V. Ravimisest mõjustusega. // Tervis, 1934; 10: 158-159.

69 Lind S. 1920.-1934. a. peetud Eesti Arstidepäevade ja kongresside resolutsioonide ja sooviavalduste teostamisest // Eesti organiseeritud arstkond 1912-1937. 1938. $-353-384$. 
academic healing practitioners. As the director of a modern health care museum, a well-connected, respected person in medical circles and an official responsible for the public health campaigns and lectures the Museum carried out extensively in the 1920s and 1930s, Sumberg might, by that time, have found it unsuitable to stick to his previous opinions. It is not entirely impossible that his personal views on folk medicine indeed became more critical over the years.

It must be remembered that from the very beginning, one of the Museum of Hygiene's wider goals was to fight against harmful remedies used by the population, which in turn does not really help promoting the good sides of folk medicine (which, as Sumberg himself pointed out, are also present), as that might have been (and was) seen, as a further encouragement of the use of (potentially) harmful folk remedies and help from folk healers.

\section{Restoration of the Estonian Health Care Museum}

In the 1970s, a group of active medical historians, physicians and others campaigned for the founding of a health care museum in Estonia. ${ }^{70}$ Although the pre-war museum was mentioned in the article, the main emphasis was on founding the museum, not restoring one. While complaining that documents, different materials and items had been scattered across the country and that much of the historical records were in private possession, the group of authors pointed out Rīga Pauls Stradiņš Museum of History of Medicine as an example of how the museum should give an overview of the history of health care and medical science in Estonia. Their colleagues were called upon to donate any relevant records to the newly found museum, also mentioning materials on folk medicine.

A few years later, in a small newspaper article, celebrating in its modest way the anniversary of the opening of the original Museum, Viktor Kalnin, a medical historian and, at the time, university lecturer and Kaljo Kiili, the chief doctor of the Tartu City Centre of Sanitation and Epidemiology

\footnotetext{
70 Ajasta N., et al. Asutagem Tervishoiu Muuseum // Nõukogude Eesti Tervishoid,
} 1970, 5: 398. 
suggested the possible use of the former building of the Museum as a place for permanent exhibition on medical history and, in the future, also the related research, as the medical students and wider public in Tartu had lacked such a place for some time. ${ }^{71}$ That suggestion, however, was not followed.

In the late 1970s, the plans to open a health care museum re-emerged when, following traditions, the exhibits of the new exposition were ordered from the Hygiene Museum in Dresden. At first, the museum was opened in Tallinn under the name of Health Care Museum of the National House of Sanitary Education on January 31, 1980 and located in the premises of the Tallinn Medical School. In the late 1980s, two joint houses at Lai Street in the Tallinn Old Town were renovated to suit the purposes of the museum and on August 1, 1989 the museum was re-opened once again as the Estonian Health Care Museum, along with the brand new exposition again ordered from Dresden. ${ }^{72,73}$

The current Estonian Health Care Museum does not possess a collection on folk medicine.

\section{Conclusion}

Voldemar Sumberg's efforts to collect and preserve folk medicine were remarkable, especially as he actively tried to involve his colleagues and medical students in recording folk medicine. The general opinion of his colleagues was by and large against folk practices, and Sumberg himself pointed out the down-side of non-medical curing. Sadly, there is little left of the collection of texts and folk healing instruments, as there is hardly anything left of the original Museum, with the exception of the building, which still stands in Tartu. A lot of interesting and valuable data has been lost with time, while, paradoxically, Sumberg's goal had been precisely to save such information from disappearing into history.

${ }^{71}$ Kalnin V., Kaljo K. Kui Tartus asutati Tervishoiu Muuseum // Edasi, 1974; $304: 4$.

72 Aimla M.-A. Eesti Tervishoiumuuseum 1980-1944 / Dr. Voldemar Sumberg ja Eesti Tervishoiu Muuseum. Meditsiiniajaloopäevade ettekandeid. - Tallinn: Eesti Tervishoiu Muuseum, 1995. - Pp. 33-41.

73 Aimla M.-A. Eesti Tervishoiu Muuseum - 75 / Terviseleht, 1999 // http://www. terviseleht.ee/199947/47_muuseum.php (6.07.2011). 
The Estonian Museum of Hygiene's collections in general were destroyed, melted or sold in the 1940s; a lot was simply carried off. The work of Voldemar Sumberg and his colleagues over two decades was brought to nothing in just a few years. One cannot be sure what happened to these folk medicine items and papers, which were not archived in the Estonian State Archives - i.e. the majority of the manuscripts, answers to questionpostcards, healing instruments for cupping, blood-letting, pulling out teeth; and photos taken by students during field-work. As well, there is the confusion as to the exact amount (in lines) of the manuscript material in total. Therefore, the amount of material to be analysed was considerably smaller than was expected in the beginning.

It should be safe to say that the missing part of the folk medicine collection was destroyed during wartime and later years. At the same time, putting together the context of this particular collection and collecting work has been somewhat demanding, as the necessary sources were scattered between different museums and archives, and this research has been more about finding the gaps, rather than filling them in. Nevertheless, one gap has been filled in with the help of this research, namely by pointing to a forgotten collection, which, in a smaller scale, still holds important information on the history of collecting Estonian folk medicine and the healing methods used by people.

\section{Godātās un zaudētās zināšanas: tautas medicīnas krājums Igaunijas Veselības kopšanas muzejā 20. gs. sākumā}

\section{Kopsavilkums}

Pievēršanās tautas medicīnas vēsturei Igaunijā sākās vēl pirms Veselības kopšanas muzeja dibināšanas 1922. gadā. Ļoti nozīmīgu ieguldījumu šīs jomas izpētē devis muzeja direktors Voldemars Sumbergs (1893-1965). Sabiedrības uzmanību tautas medicīnai viņš pievērsa, vēl būdams medicīnas students, ar publikāciju tolaik populārajā žurnālā "Tervis" ("Veselība"). 
Kad V. Sumbergs kḷuva par muzeja vadītāju, viṇš tautas medicīnas materiālu un zināšanu krājuma veidošanā centās iesaistīt Igaunijas ārstus un veterinārārstus, skolotājus u. c.

Par vienu no jaunā muzeja stūrakmeņiem kḷuva muzeja darbinieku centieni ne tikai savākt materiālus, bet arī tos analizēt un popularizēt uzzināto. Krājumu veidošanu vadīja un iedvesmoja Voldemārs Sumbergs, ko padomju vara pakḷāva arestam un deportēšanai. 20. gs. 50. gadu sākumā muzeja aktīvajai darbībai pienāca noriets.

Savāktie materiāli glabājas vairākos Tallinas un Tartu muzejos un arhīvos. Tie joprojām ir bagātīgs izpētes avots medicīnas vēstures speciālistiem.

Ave Goršič, $P h D$

Estonian Folklore Archives, Tartu

avetupits@folklore.ee 